\title{
Proximate Analysis and GC - MS Analysis of Essential Oil Leaf Extracts of Mistletoe Plant
}

\author{
Tabe . N. $\mathbf{N}^{1}$, Ushie.OA ${ }^{2 *}$ Jones. B. $\mathbf{B}^{\mathbf{1}}$, Ojeka .C ${ }^{\mathbf{1}}$ \\ ${ }^{1}$ Department of Chemical Science, Cross River University of Technology Calabar, Nigeria \\ ${ }^{2}$ Department of Chemical Science, Federal University Wukari Nigeria
}

*Corresponding Author: Ushie.OA, Department of Chemical Science, Federal University Wukari Nigeria

\section{INTRODUCTION}

Routine chemical analysis of plants can be used to predict the nutritive, phytochemical (therapeutic properties) and essential oil content. Mistletoe plant is a hemi-parasitic plant that grows on trees such as cocoa, mango, guava, kola nut trees and many more is known scientifically for its nutritive content such as carbohydrate, protein, fat, fiber, energy value, and ash (Tabe et al., 2018). These nutritive contents contributes remarkably in animals and human health. Mistletoe leaves have been known for its use in the treatment of some ailments including hypertension, epilepsy, infertility, arthritis, cancer and diabetes or used as a diuretic agent (Simeon, Illoh \& Imoh (2013). Essential oils are concentrated hydrophobic liquids containing volatile (defined as "the tendency of a substance to vaporize") aroma compounds found in some plants. Mistletoe leaves also contain essential oil which could be a good anti-inflammatory substance since it contain n-hexadecanoic acid that have been reported to exhibit anti-inflammatory properties. (Odunayo \& Ibrahim., 2016). The aim of this research was to determine and compare the proximate composition and essential oil content of mistletoe leaves. The result can be used to classify the plant as a possible source of these constituents and by extension its usefulness in nutritional, medicinal and health needs of Nigerians and by extrapolation to other nations. Mistletoe leaf could serve as a source of essential nutrient which can go a long way in ameliorating most nutritional challenges and may contribute remarkably to the amount of nutrients in human (Franklin et al., 2017). Another analysis of mistletoe sample carried out from different host plant such as cocoa, kola and coffee trees shows that the samples contain varying amount of moistures, ash crude protein, fibre and carbohydrate. They was a wide variation in the ash content of the mistletoes from the different hosts with that obtained from cocoa having the highest value of $20.37 \%$. This is indicative of the presence of high amount of inorganic matter (Olusola, 2015). The mistletoe leaf are known to carry out important medicinal roles in human body as a result of the presence of flavonoids in the hexane, chloroform and ethyl acetate extracts from the stem bark. Flavonoids have inherent ability to modify the body's reaction to allergens viruses and carcinogens. They show anti-allergic, antiinflammatory, antimicrobial, antioxidants, Salah et al.; 1995 Okwu 2004 (Cushnie and Lamb 2005, Salah et al.; 1995 Okwu 2004).

\section{Materials AND Methods}

\subsection{Collection and Preparation}

The mistletoe samples used were collected from Cross River University of Technology Staff Quarters from a cocoa tree. The analysis for the phytochemical composition and proximate analysis and oil extraction of the plant was carried out in the chemistry laboratory of chemical sciences department, Cross River University of Technology (CRUTECH), Calabar, Cross River State, Nigeria. The plant material was identified by the department of biological sciences of Cross River University of Technology (CRUTECH). The leaves were divided into two, a portion were used for oil extraction and moisture content while the rest were dried in an electron oven for 3 hours. After drying, the samples were crushed to powder form using mortar and pestle. The sample in powdered form was stored in bottle till require for analysis. 


\subsection{Proximate Analysis}

The fresh leaves of mistletoe were separated and some were used for moisture content while the others were dried and grinded into powder and stored in a container for other analysis. The method adopted for the study was the gravimetric method of the Association of Official Analytical Chemist (A.O.A.C, 2005).

\subsection{Determination of Moisture Content}

The moisture content of the whole leaf of mistletoe were determined by first washing the crucible thoroughly and dried in an oven, and empty weight of the crucible is taken (W1). $2.0 \mathrm{~g}$ of fresh seed of the sample was introduced into the dried crucible and weight (W2), the sample is ten dried in a ventilated electronically heated oven at $60 \%$ for 24 hours, cold in a desiccators containing magnesium sulphate as drying agent and reweighted.

Moisture $(\%$ weight $)=\frac{\text { Loss of wieight on drying } \times 100 \%}{\text { Initial samplet weight }(g) \times 1}$

\subsection{Determination of Ash Content}

To measure the ash content of the sample two empty crucible was weighted and $2.0 \mathrm{~g}$ of the sample (mistletoe leaf) was accurately weighted into crucible and put in a muffle furnace and ashed at $6000 \mathrm{c}$ for 3 hours. At the end of the ashing period, the ashed sample were removed into the desiccators for cooling to room temperature and reweighed.

Calculation for Ash content $=(\%$ weight $) \frac{=\text { Weight of fresh sample } \times 100}{\text { Intial wt of sample } \times 1}$

\subsection{Determination of Fiber Content}

To measure the fibre content of the sample (mistletoe leaves) is based on two digestion;

\section{Acid digestion}

The fat free material stored in the thimble was weighted and transferred into $400 \mathrm{ml}$ beaker. $50 \mathrm{ml}$ of $1.25 \% \mathrm{H}_{2} \mathrm{SO}_{4}$ was added and the mixture was made up to $200 \mathrm{ml}$ with distilled water. The content of the beaker was filtered through a Buchner funnel with the use of suction pump. The residue was wash with warm distilled water until it was acid free.

\section{Base Digestion}

The residue left after acid digestion was transferred into a $400 \mathrm{ml}$ beaker, $50 \mathrm{ml}$ of $1.25 \% \mathrm{NaOH}$ was added and made up to $200 \mathrm{ml}$ mark with distilled water.

The mixture was again heated for 30 minute with constant starring. The content of the beaker was filtered using Buchner funnel and washed several times with hot water until it was free from sodium hydroxide. Finally, the residue was washed twice with $95 \%$ of methanol. This was transferred into a crucible and dried at $100^{\circ} \mathrm{C}$. The weight of oven dried sample was noted and the residue was ignited in a furnace at $550^{\circ} \mathrm{C}$, the weight of ash left after ignition was also noted. This was done for both the leaves and flower (A \&B) and calculation was done using the formula below;

$$
\frac{C-A \times 100 \%}{A} \text { or } \frac{\text { Weight of sample }(\text { ash })}{\text { Initial wight of the sample }} \times \frac{100}{1}
$$

\subsection{Determination of Crude Protein Content}

$5.0 \mathrm{~g}$ of the grinded sample (mistletoe leaf) was weighed into $250 \mathrm{ml}$ standard kjeldahl flask containing 1 table standard kjeldahl catalyst, some antibumbing chip and $30 \mathrm{ml}$ of concentrated $\mathrm{H}_{2} \mathrm{~S}_{4}$ was introduced into the flask. The flask was lock into digestion rock and heated gently for 1 hour to prevent vigorous choking and frothing, the flask was ten subjected to vigorously heating for 8 hours until a clear bluish colour was obtained. After the digestion the flask was cooled in tap water and quantitatively transferred into $100 \mathrm{ml}$ standard volumetric flask and make up to mark with distilled water. $10 \mathrm{ml}$ portion of the digested sample was measured into a semi microkjeldahl Mackham distillation apparatus and treated with $30 \mathrm{ml}$ of $40 \% \mathrm{NaOH}$ into $100 \mathrm{ml}$ beaker containing $10 \mathrm{ml}$ of $2 \%$ boric acid plus 2 drops of double indicator $(0.1 \%$ methyl reagent and $0.1 \%$ methyl blue in $100 \mathrm{ml}$ of ethanol). The tip of the condensed receiver was immersed in the boric acid, double indicator and the distillation continued until about 3 times the original volume was obtained the distillate was then titrated with $0.1 \mathrm{~m} \mathrm{HCl}$ solution until a purple-pink end point was reached. The percentage nitrogen content in the sample was obtain with appropriate calculation. 
Calculation for \% Nitrogen (protein)

$=\frac{\% \text { Nitrogen }=N / 10 \times \mathrm{Hcl}(\mathrm{ml}) \times D F \times N F \times 100 \%}{\text { Weight of sample in milligrame }}$

The protein was determined by multiplying the percentage of nitrogen by the factor 6.25 .

\subsection{Determination of Fat Content}

$5.0 \mathrm{~g}$ of sample (leave \& flower of mistletoe) was weighed into a thimble and place in a soxhlet extractor, and $130 \mathrm{ml}$ of petroleum ether (boiling Point $40-60^{\circ} \mathrm{C}$ ) was poured into a previously dried weighted round bottomed flask. The soxhlet apparatus was set up with condenser connected to the tap inlet and outlet, few chips of antibumbing was placed in the round bottomed flask containing ether. The flask was heated on the hot plate for 10 hours, as the oil was extracted the thimble, was then removed and oil dried fat free extract was then used for fibre determination). The petroleum ether in the flask was distilled off and collected and stored for subsequent use. The flask and its content was again dried and weighed accurately. The amount of lipid extracted was obtained as the difference between the weight of the flask before and after.

Fat $(\%$ weight $)=\frac{\text { Weight of } \text { fat }}{\text { Weight of sample }} \times \frac{1000}{1}$

\subsection{Determination of Total Carbohydrate Content}

The calculation is conveniently done by the differential method total $\mathrm{CH}=100-(\%$ Moisture + $\%$ Ash + $\%$ Fat $+\%$ Protein $+\%$ Fiber $)$ )

\subsection{Determination of Total Energy Value}

\section{Energy content}

the kilocalories $(\mathrm{kcal} / 100 \mathrm{~g})$ value estimation was done by summing the multiplied values for crude protein, crude lipid (excluding crude fibre) and carbohydrate respectively at water factor (4, 9 and 4 kcal) as thus:

Energy value $(\mathrm{kcal} / 100 \mathrm{~g})=$ crude protein $\mathrm{x} 4)+($ crude fat $\mathrm{x} 9)+($ total carbohydrate $\mathrm{x} 4)$.

\section{Oil Extraction Procedures}

Fresh leaves and flower of the sample (mistletoe) was feed into a round bottom flask and placed in a soxhlet extraction and $100 \mathrm{ml}$ of distilled water was poured into it. The soxhlet apparatus was setup with condenser connected to the tap inlet and outlet, few chips of antibumbing was placed in the round bottom flask containing the sample with distilled water. The flask was heated on the hot plate for 10hours.

The flask was removed when the clear extract was observed and the extract was turn into a separating funnel and few drops of $n$-hexane was added and shaken for few minute and kept for some time. Since the oil is lighter than the water, the oil was observed as the upper layer while the water was the bottom layer. The tap of the separating funnel was opened the water layer was separated from the oil.

\section{RESUlTS AND DISCUSSION}

Table1. Result of Proximate Analysis of Leaves

\begin{tabular}{|l|l|}
\hline Parameter s & Leaves \% \\
\hline Moisture contain & $29.04 \pm 0.24$ \\
\hline Fiber contain & $10.05 \pm 0.08$ \\
\hline Fat contain & $5.84 \pm 0.08$ \\
\hline Protein contain & $2.09 \pm 0.34$ \\
\hline Ash content & $11.49 \pm 0.08$ \\
\hline Carbohydrate & 41.27 \\
\hline Energy value & $227.1 \mathrm{kcal} / 100 \mathrm{~g}$ \\
\hline
\end{tabular}

Note: Result is mean of triplicate of samples

Table2. GC - MS Analysis of Essential Oil Leaves of Mistletoe Plant

\begin{tabular}{|l|l|l|l|}
\hline $\mathbf{S} / \mathbf{N}$ & Name and Molecular Formula & $\%$ composition & $\begin{array}{l}\text { Retention } \\
\text { time }(\mathrm{min})\end{array}$ \\
\hline 1 & Methyl-cyclohexane $\mathrm{C}_{7} \mathrm{H}_{14}$ & 16.94 & 3.27 \\
\hline 2 & Ethyl-cyclohexane $\mathrm{C}_{6} \mathrm{H}_{12}$ & 4.003 & 3.41 \\
\hline
\end{tabular}




\begin{tabular}{|l|l|l|l|}
\hline 3 & $1,2,3$-trimethoxy-cyclopentane $\mathrm{C}_{8} \mathrm{H}_{16}$ & 2.51 & 3.45 \\
\hline 4 & Toluene $\mathrm{C}_{7} \mathrm{H}_{8}$ & 33.75 & 3.59 \\
\hline 5 & 1-4-cycloheanedimedimethanol $\mathrm{C}_{7} \mathrm{H}_{16} \mathrm{O}_{2}$ & 2.88 & 3.66 \\
\hline 6 & 1,2 -dimethanol,diacetate cyclohexane $\mathrm{C}_{12} \mathrm{H}_{20} 0_{4}$ & 1.95 & 3.75 \\
\hline 7 & Docdecanoic acid $\mathrm{C}_{12} \mathrm{H}_{24} \mathrm{O}_{2}$ & 10.05 & 26.29 \\
\hline 8 & Dodecanoic acid $\mathrm{C}_{12} \mathrm{H}_{24} \mathrm{O}_{2}$ & 4.09 & 26.29 \\
\hline 9 & 3,5 -dimethylundecane & 0.45 & 26.86 \\
\hline 10 & 2-methyl-6-propyl-dodecane $\mathrm{C}_{12} \mathrm{H}_{34}$ & 2.3 & 27.69 \\
\hline 11 & 2,6,11-trimethyl-dodecane $\mathrm{C}_{12} \mathrm{H}_{28} \mathrm{O}_{2}$ & 4.25 & 27.87 \\
\hline 12 & Tetradecanoic acid $\mathrm{C}_{14} \mathrm{H}_{28} \mathrm{O}_{2}$ & 2.07 & 27.89 \\
\hline 13 & Nonadecane $\mathrm{C}_{19} \mathrm{H}_{4} \mathrm{O}_{2}$ & 1.24 & 28.34 \\
\hline 14 & Eicosane $\mathrm{C}_{20} \mathrm{H}_{24} \mathrm{O}_{2}$ & 5.14 & 28.86 \\
\hline 15 & Hexadecane $\mathrm{C}_{16} \mathrm{H}_{34}$ & 1.90 & 29.67 \\
\hline 16 & Tetracosane $\mathrm{C}_{34} \mathrm{H}_{50}$ & 1.41 & 30.32 \\
\hline & TOTAL & $100 \%$ & \\
\hline
\end{tabular}

\section{DISCUSSION}

The results of the proximate compositions of mistletoe leaves are presented in Table 1 which indicates that moisture, crude fibre, fat, protein, ash, carbohydrate and energy content are $29.4 \% 10.05 \%, 5$. $84 \%, 2,09 \% 11.49 \%, 41.27 \%$, and $227.1 \mathrm{kcal} / 100 \mathrm{~g}$ for leaves. The leaf is rich in carbohydrate, fats, fiber, ash, with low protein content. It also has a high energy value the moisture content was high (29.04\%) the high moisture content of the fresh leaves show that it is very nutritious and useful for medicinal and industrial purposes. The fat content was 5.84\% for leaf and it have been recommended to avoid problem of obesity (Lintas, 1992). Crude fiber contents in the leaf is $10.05 \%$. Crude fiber as reported by Ishiwu et al. (2013) helps in lowering the level of serum cholesterol, lower breast cancer risks as well as risks of coronary heart diseases.

The high energy value with good amount of carbohydrate contents is $227.1 \mathrm{kcal}$ for leaves and a low amount of protein $(2.09 \%)$. The percentage yield and retention time (minutes) of essential oil of mistletoe leaves are presented in Tables 2. The GC-MS analysis of mistletoe leaves revealed that 16 compounds were detected from the oil in the leaves. The trend in decreasing order of the percentage content of the compounds detected in leaves extract is Toluene (33.75\%), Methyl-cyclohexane (16.94\%), Docdecanoic acid (10.05\%), Eicosane (5.14\%), Dodecanoic acid (4.09\%), Ethylcyclohexane (4.00\%), 1-4-cycloheanedimedimethanol(2.88\%), 1,2,3-trimethoxycyclopentane(2.51\%),2-methyl-6-propyl-dodecane(2.3\%), Tetradecanoic acid (2.07\%), 1,2dimethanol,diacetate cyclohexane(1.95\%), Hexadecane $(1.90 \%)$, Tetracosane $(1.41 \%)$, Nonadecane $(1.24 \%)$ and 3,5-dimethylundecane $(0.45 \%)$ while the trend for flower is Eicosyl vinyl ester carbonic acid (19.94\%), Heptadecyle isobutyl ester carbonic acid (17.81\%), Dimethyl- sitanediol (16.46\%), Heptadecyle isobutyl ester carbonic acid (16.02\%),9- methyl- Nonadecane (15.58\%),1- bromoei cossane $(5.11 \%)$, Trimethisily fluoride $(4.07 \%), 3$, 5, 24- trimethyl- tetracontane (1.87\%), Crotyl methacrylate (1.74\%) and Eicosyl prop- len-zylester carbolic acid (1.44\%). The presence of Dodecanoic (Lauric) acid in the leaves in an indication that it can be used to check microbial activities. Tetradecanoic (Myristic) is acid associated with increase in serum level of low-density lipoprotein cholesterol. Most of the saturated hydrocarbons detected serve as precursor in the manufacture of petrochemical products.

\section{REFERENCES}

[1] AOAC. (2005). Official method of Analysis. Association of Official Analytical Chemist,

[2] Washington DC, USA, $15^{\text {th }}$ edition.

[3] Cushnie, T. P. T, Lamb, A. J (2005). Antimicrobial activity of flavonoids. International Journal of Antimicrobial Agents, 26 (5) : 343-356.

[4] Franklin, U. O, Olubunmi, A. W.\& Anthony, J. A. (2017) Proximate composition and Mineral Analysis of Phragmantera Capitata (Sprengel) Balle, A mistletoe growing on Rubber Tree. Research Journal of Botany, $12: 23-31$

[5] Ishiwu, C. N., Obiegbuna, J. E., Aniagolu, N. M. (2013). Evaluation of chemical properties of Mistletoe leaves from three different trees, (avocado. Africana oil bean and kola) Nigerian Food Journal vol 31. 1-7.

[6] Odunayo, C. A \& Ibrahim, A. O. (2016). Comparison of Chemical Compositions of Essential Oil from the fresh and dried leaves Tapinanthus bangwensis (Engl. And K. Krause) Danser [Loranthaceae]. American Journal of Essential Oils and Natural Products, 4(3) :31-33. 
[7] Okwu D 2004. Phytochemicals and vitamin content of indigenous species of south-eastern Nigeria. J. Sustain. Agric. Environ., 6(1): 30-37.

[8] Olusola, O. O. and Adoge (2014). Evaluation of the Phytochemicals and Microbial Inhibitory Properties of Piper Guineensii and Buchhlozia coriacea seeds of Nigerian Origin. Global Journal of Medical Research : C Microbiology and Pathology (14)7.

[9] Pavia, Donald L., Gary M. Lampman, George S. Kritz, Randall G. Engel (2006). Introduction to Organic Laboratory Techniques (4th Ed.). Thomson Brooks/Cole. pp. 797-817.

[10] Salah, W., Milter, N. J., Pagauga, G., Tijburg, G., Bolwel, A. P., Rice, E. and Evans, C. (1995) Prlyphenolic flavonoids as scavengers of aqueous phase radicals as chain breaking oxidant. Archives of Biochemistry and Biophysics, 2 :339-346.

[11] Simeon, K. A., Illoh, H. C., Imoh, I. J. \& Imoh E. J. (2013). African mistletoe (Loranthaceae), Ethropharmacology, Chemistry and medical value : African Journal of Traditional, Complementary and Alternative Medicine. 10(4) 161-170.

[12] Tabe, N. N, Ushie, O A, Jones, B. B, Kendenson, A. C Muktar, M. \& Ojeka, C. U. Phytochemical Analysis of Methanolic Extract of Mistletoe Leaf. Journal of Advanced Research in Chemical Science (IJARCS). 5(7) 77-11

Citation : Ushie.OA, et al., (2019). Proximate Analysis and GC - MS Analysis of Essential Oil Leaf Extracts of Mistletoe Plant. International Journal of Medicinal Plants and Natural Products (IJMPNP), 5(3), pp.17-21. http://dx.doi.org/10.20431/2454-7999.0503003

Copyright: (C) 2019 Authors, this is an open-access article distributed under the terms of the Creative Commons Attribution License, which permits unrestricted use, distribution, and reproduction in any medium, provided the original author and source are credited. 